\title{
DEGRADE AND VALUE LOSS IN FIRE-KILLED PINE IN THE MISSISSAGI AREA OF ONTARIO ${ }^{1}$ \\ By M. L. PREBBLE ${ }^{2}$ and L. M. GARDINER ${ }^{3}$
}

L. M. Gardiner was born in 1924 at Ottawa, where he received his early education. He served in the R.C.A.F., 1942-45. He received a B.Sc.F. degree from U.N.B. in 1949, an M.Sc. degree from McGill University in 1952, and a Ph.D. degree in 1955, also from McGill. He joined the staff of the Forest Insect Laboratory, Sault Ste. Marie, Ontario, in 1947. He is a member of the C.I.F., and has served several terms on the Editorial Board of The Forestry Chronicle.

\section{INTRODUCTION}

Salvage of timber killed by fire is frequently limited in time by the effects of wood-boring insects, sap stains and wood-rotting fungi. Kimmey and Furniss (1943) found that insects and fungi were interdependent agents of deterioration of fire-killed Douglas fir in Oregon and Washington. Deterioration was most rapid in the upper part of the tree, and in young stands. Within any one age-class, heartwood deterioration progressed more rapidly in trees with rapid growth. Deterioration appeared to be more rapid in areas where borer populations had already built up in dead timber resulting from earlier fires.

Borer attack in fire-killed white spruce in Saskatchewan was related to burn type (Richmond and Lejeune, 1945). Trees with bark burned thin were immune to borer attack. Moderately burned trees were attacked earliest and by the deep-boring species. Trees with bark subjected to killing heat, but not burned, and trees whose roots were injured, were attacked latest and predominantly by shallow-boring species.

The progress of sapwood decays in fire-killed spruce, balsam fir, and jack pine in Quebec was inversely proportional to the severity of burn and was most rapid in balsam fir, other factors being equal (Skolko, 1947).

Great quantities of eastern white, red, and jack pine (Pinus strobus L., $P$. resinosa Ait., and $P$. banksiana Lamb.) timber were killed in the 645,000acre Mississagi-Chapleau fires of May and June, 1948. Wood borers attacked about three-quarters of the killed jack pine trees, about one-half of the killed white pine, and about one-quarter of the killed red pine trees in the summer of 1948, and were at moderate depths (over one inch) by August. Practically no trees that retained green foliage in 1948, even though charred in the lower trunk, were attacked by borers that year. Subsequent field investigations (Gardiner, 1957) showed that nine species of cerambycid wood-borers infested pine that was dead or dying as a result of the fire, the deep-boring Monochamus species being the most important. Damage by these beetles was greatest in white pine trees, and in trees of all species that suffered severe fire injury and were killed outright at the time of the fire. The progress of wood-staining

\footnotetext{
${ }^{1}$ Contribution No. 385, Forest Biology Division, Science Service, Department of Agriculture, Ottawa, Canada.

${ }^{2}$ Chief, Forest Biology Division, Ottawa, Canada. Biographical reference, For. Chron. $31: 314$. ${ }^{3}$ Forest Insect Laboratory, Sault Ste. Marie, Ontario.
} 
and wood-rotting fungi in fire-killed pine over the five-year period following the Mississagi fire was the subject of a separate study (Basham, 1958).

Deterioration studies, based on sample blocks from different portions of the trunk, provide useful records of the progress of the agents of deterioration, usually in the form of percentages of the total or merchantable volume affected. The results, however, do not have a direct application in saw-log operations, because much of the affected volume is converted into slabs, edgings, and sawdust. Moreover, it is loss of grade and hence of value, rather than loss of volume output, that is important in sawlog salvage operations. Mill studies were, therefore, undertaken to provide data on grade and value loss, to supplement the studies on the factors causing deterioration. The mill study was made possible through the co-operation of the Division of Timber Management, Ontario Department of Lands and Forests, and Mr. R. F. Tetreault, logger and mill operator in Township 3D, near Rocky Island Lake. Mr. Tetreault's mill was made available for the studies at the conclusion of the sawing season. Mr. W. Desbiens, sawyer, carried out the sawing and edging. The crew required for logging, handling, and examination of the lumber, was drawn from the staff of the Forest Insect Laboratory. Logging and milling were carried out during November, 1949.

The present report is concerned exclusively with those aspects of the data that relate to grade and value of the lumber as influenced by tree species and severity of fire injury.

Although all three pine species were sampled, the results for jack pine are not reported here since most trees comprising the sample were overmature and of low quality. They did not reflect the effects of deteriorating agents as non-defective trees would have done.

\section{Selection of Trees}

METHODS

Trees were selected to represent the full range of fire injury. In white and red pine, injury ranged from complete denudation of the foliage by crown fire and immediate death, through heavy scorching of the lower trunk and gradual dying of the trees during 1948, to light scorching of the lower trunk and roots followed by gradual dying of the trees during 1949 or later. In jack pine, all the sample trees had been killed at the time of the fire, either by complete denudation by crown fire, or by severe scorching of the trunk and loss of most of the foliage.

Sample trees were taken from three stands in the southern portion of Township 3D, which had been burned in the interval May $26-30,1948$. The stands are described below.

\section{Stand A}

A 140-150-year-old stand of red pine and jack pine, with occasional white pine and spruce on flat, gravelly terrain. The fire had been very intense. Many trees were killed by crown fire, others by hot ground fire (brown foliage adhering in 1949). A few red pine trees survived the fire, but no white pine, 
jack pine, or spruce trees survived. Of twenty-eight trees taken from Stand A, average dimensions were as follows:

D.B.H. (inches)

Height (feet)

Crown Length (feet)

White pine
16
85
49

Stand $B$

A 220-230-year-old stand of white pine with occasional red pine, on rich soil on an upland flat, bordered by gentle slopes. The fire had been very patchy. Numerous clumps of trees had been missed by the fire. The ground fire was evidently light, judging by light charring of tree trunks and persistence of small twigs on dead understory balsam fir saplings. Most of the dead trees had been killed by crown fire. Twenty-two trees were taken from Stand B, with average dimensions as follows:

$$
\begin{aligned}
& \text { D.B.H. (inches) } \\
& \text { Height (feet) } \\
& \text { Crown Length (feet) }
\end{aligned}
$$
Red pine

\section{Stand $C$}

A 150-200-year-old stand of white pine, red pine, jack pine, white spruce and white birch on a rocky hillside. The fire had been very intense and all trees were killed. Very heavy charring occurred at the base of the trees, and most of the foliage had been burned off. Sampling was restricted to three red pine trees, which averaged 18 inches D.B.H., 87 feet in height, and 31 feet in crown length.

The burn characteristics of each tree were described before felling, and the extent of charring and dimensions of each log were recorded as bucking proceeded. Each log was identified by a number at the butt end. One-foot blocks were taken at the base of each log and also at the top of the last log from each tree, for studies of borer populations, depth of penetration, and occurrence of stain and decay. These blocks contributed information supplementary to the data obtained during milling of the logs.

\section{Severity of Fire Injury and Time of Tree Death}

Field studies of insect deterioration of pine in the Mississagi fire area (Gardiner, 1957) showed that extent of insect damage depended on the time of tree death after the fire. This was in turn governed by the severity of fire injury, which thus indirectly affected the nature and speed of deterioration. Three fire-injury classes were recognized and described as follows:

Class 1.

Severe injury

Trunks charred throughout entire length, with heavy charring on at least the lower 20 to 35 feet, char extending deep into bark and fissures, bark scales burned off in red pine, foliage almost entirely killed or consumed; 
Class 2.

Moderate injury

Trunks charred heavily at base and lightly at 20 feet or higher, or lightly charred over entire length, killing of foliage variable but rarely any consumed;

Class 3.

Light injury

Trunks lightly charred on the lower 20 to 35 feet at most, partial killing of foliage in some cases, but crown usually intact and green.

Most of the Class 1 trees were killed outright or died within six months of the fire, whereas no serious mortality occurred in the Class 2 trees for six months, and Class 3 trees escaped mortality for at least a year.

In the present study, it was impossible to ascertain the time of death of all trees sampled. However, the burn characteristics of each tree permit classifying the tree as to severity of burn injury along the lines cited above. Two groups were employed: severely injured trees, which may be regarded with reasonable confidence as embracing those killed at the time of the fire or soon after; and, lightly to moderately injured trees which generally remained alive for six months or a year after the fire. Differences in degrade and value loss in these groups were consistent with the results of the field investigations (Gardiner, 1957).

\section{Milling}

All logs were sawn into 1 -inch and 2-inch lumber, by a 52 -inch circular saw with inset teeth, operating at 650 r.p.m. and cutting one-quarter inch kerf. Edging to a maximum of 12 inches was done with a two-saw edger. Power was supplied by an 80 h.p. General Motors Company diesel engine.

Each $\log$ was sawn precisely as would have been done had the timber not been killed by fire, and had there been no attack by wood borers and sapstaining fungi, i.e. volume recovery was not reduced by heavy slabbing to get rid of defects. This was important in reaching an accurate appraisal of the influence of deteriorating agents in the fire-killed trees.

As each log was sawn, a sketch of the milling procedure was prepared by one man stationed behind the saw. An identification number was marked on each piece of lumber as it dropped on the conveyor, and after the conveyor belt had been disengaged, all pieces from each log were assembled on a series of examination tables. Generally six logs were sawn at one time and the mill was then shut down to permit examination of the lumber and recording of the data. Four two-man crews examined the pieces from the various logs, and recorded the number of borer holes and the extent of sap stain in 1-inch strips along the outside 3 inches of each piece of lumber. In boards 7 inches or less in width, the scribing was confined to the outside 2 inches of each piece. The presence of rot was also recorded. In waney boards from the outside of the log, a preliminary count of borer holes on each surface was made before edging, and the detailed records described above were made 

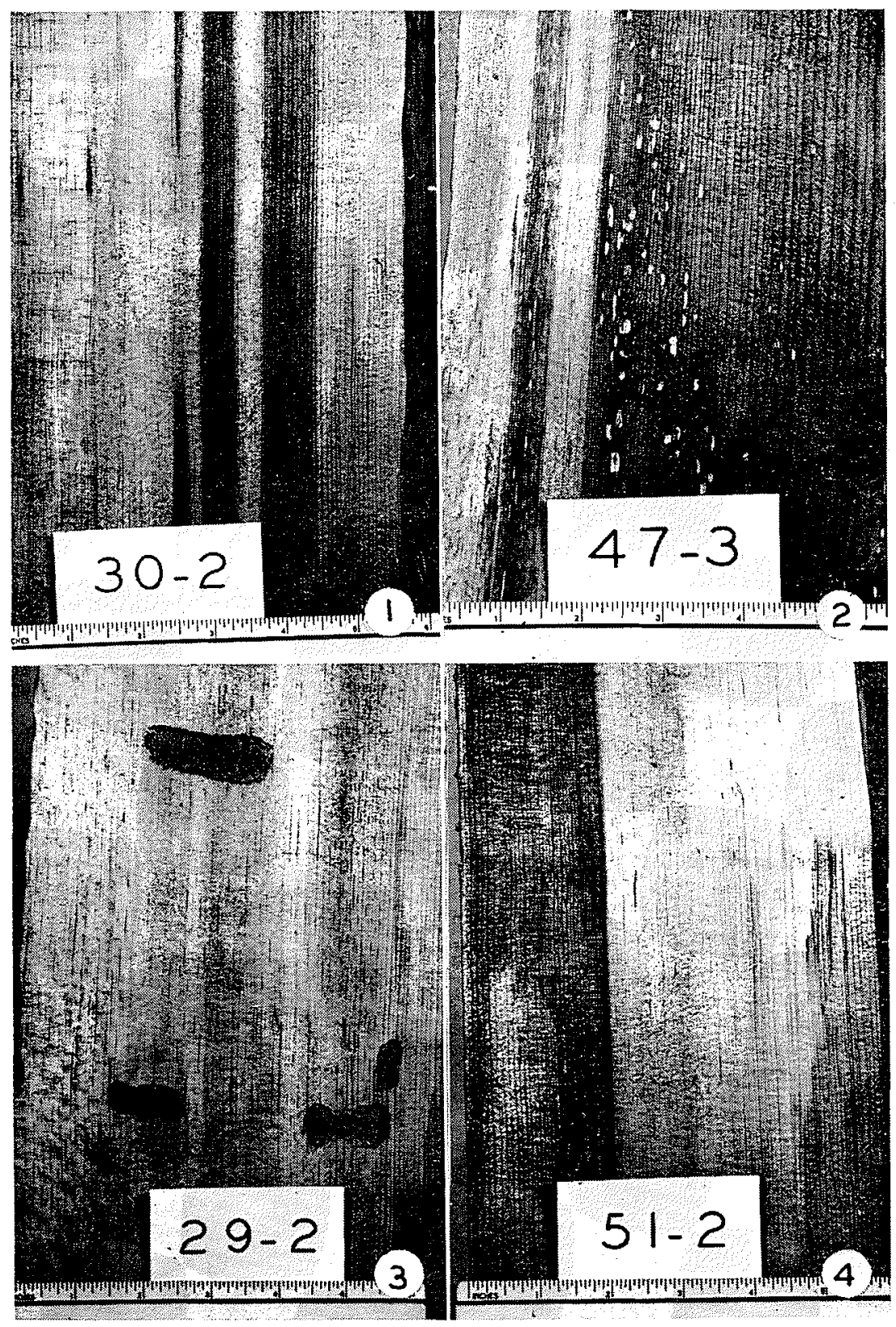

FIGURE 1: Incipient decay caused by Fomes pini, in white pine block.

FIGURE 2: Advanced decay caused by Fomes pini, in white pine block,

FIGURE 3; Deep borer penctration in a block from a white pine trec killed in May, 1948.

FIGURE 4: Heavy sap stain caused by Coratostomclla sp. in block 51-2 from a white pine tree killed in May, 1948. 


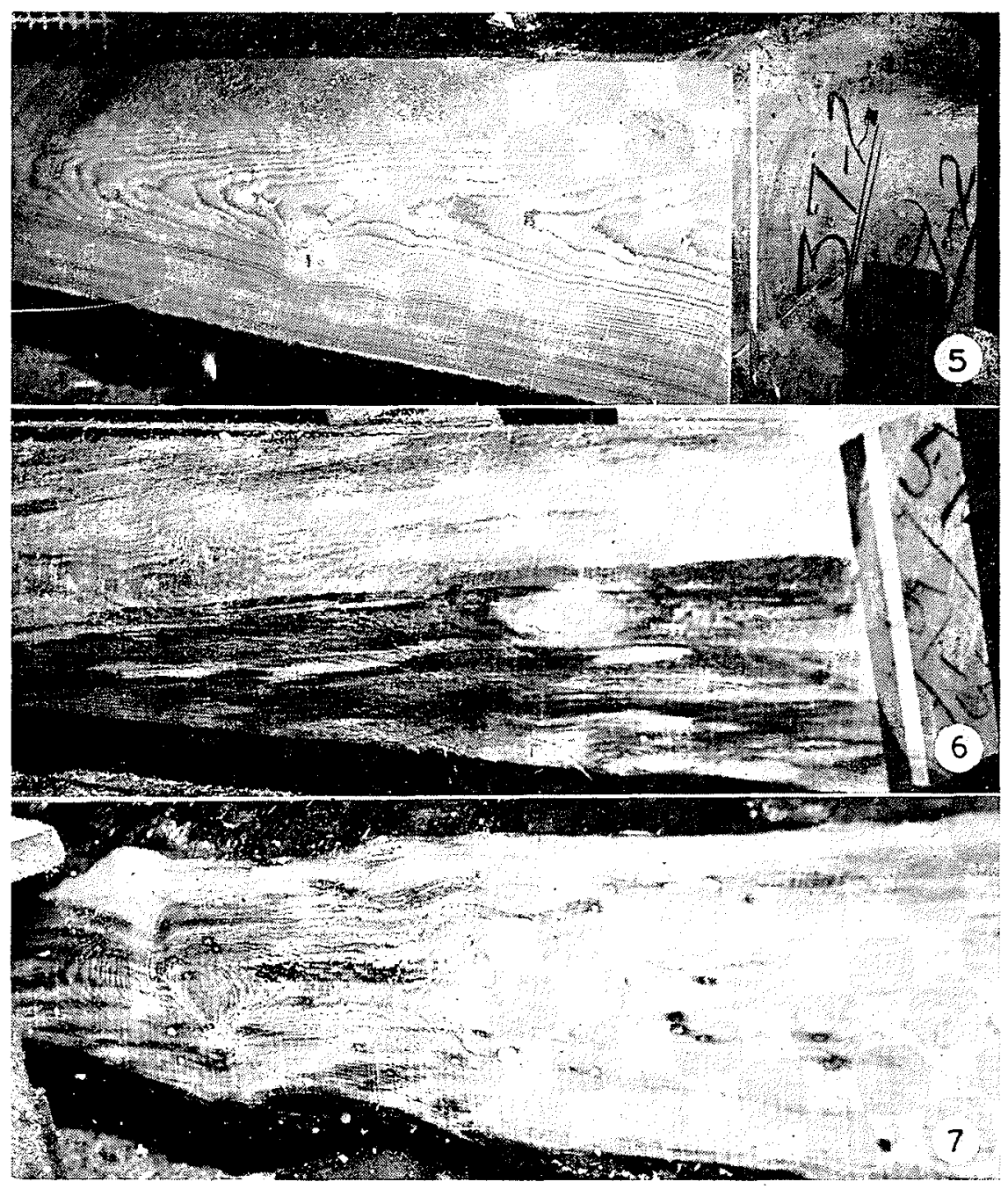

FIGURE 5: Sound, clear lumber (the face showing was graded No. 1 cut) from the second log of a large white pine tree which, although foliage was consumed in 1948 , retained its cambium in a "green" condition inco 1949. Borer attack occurred in 1949 ac heights from 33 feet and up, but the first two logs were entirely free of borers and stain.

FIGURE 6: Sap stain in piece No. 4 (degraded from No. 3 common to No. 5 common) of log 51-3 from a whice pine tree killed by crown fire in May, 1948. Borer holes were not plentiful in the lumber sawn from this log, and all degrade was caused by stain.

FIGURE 7: Borer holes and sap stain in a heavily attacked white pine log. 


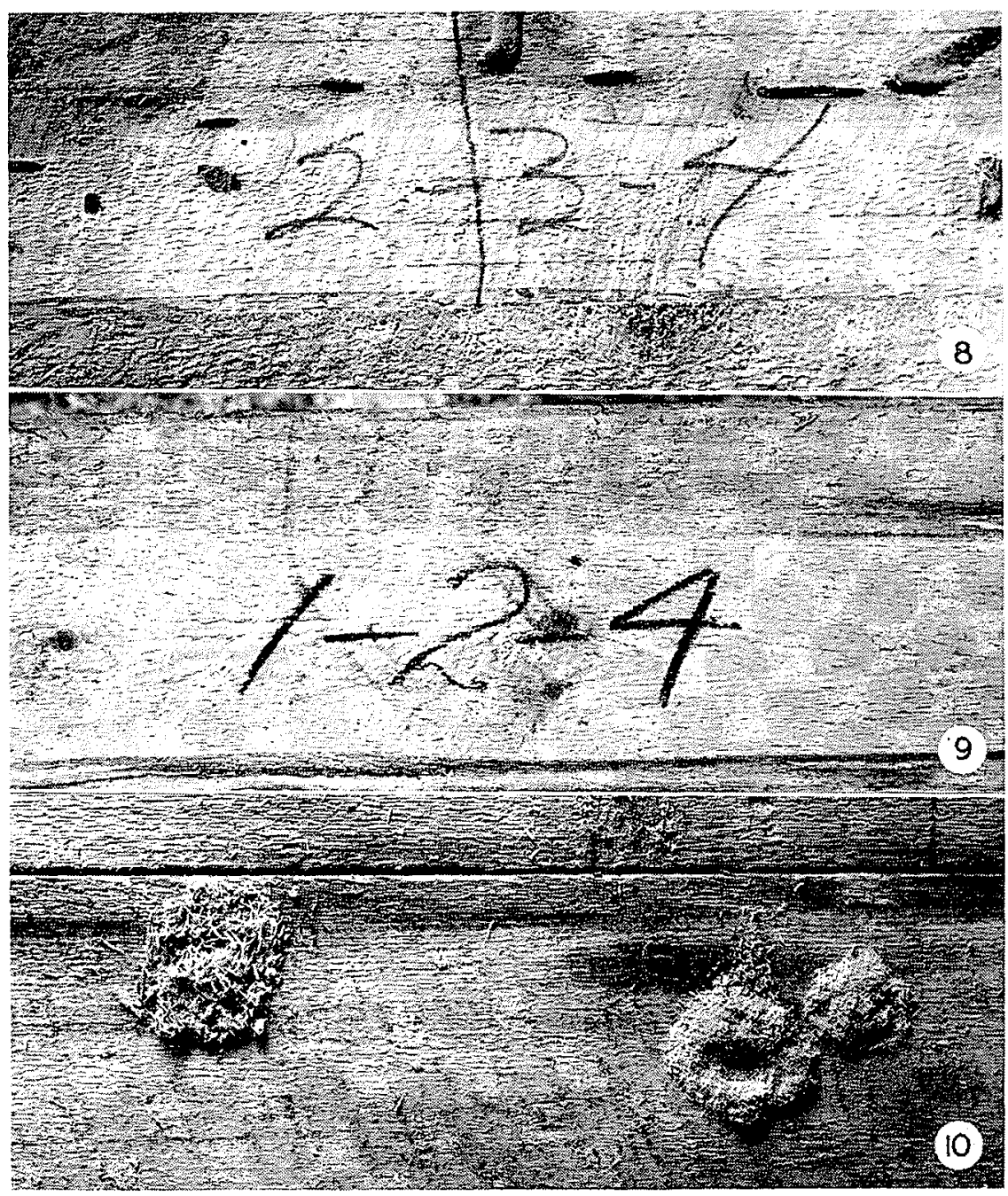

FIGURE 8: Heavy borer attack and marginal stain in piece No. 4 from log 2-3, from a white pine trec killed by fire in May, 1948. The picce was $2 \times 8 \times 14$, and was degraded from No. 2 common to No. 6 common, because of borer holes.

FIGURE 9: Heavy marginal stain, but no borer holes, in piece No. 4 from $\log 1-2$, from a red pine tree killed by fire in May, 1943 . The piece was $2 \times 10 \times 14$, and was degraded from Merchantable to No. 1 cull.

FIGURE 10: Wood fibres extruded from borer galleries in white pine lumber placed in heated storage, December 1949 to March 1950. Many of the borers completed development and emerged as adults during the period of storage. 
after edging. The records on borer holes and stain assisted materially in classifying the data for compilation, and in determining the feasibility of improving grade by re-edging.

\section{Grading}

After sawing was complete, each piece of lumber was graded by $\mathrm{Mr}$. T. M. Callaghan, then Chief Grader of the White Pine Bureau of the Canadian Lumbermen's Association. Grades for each piece were designated as follows:

(a) "original" grade, which represented the inherent quality of the piece, assuming there had been no fire and consequently no entry of borers or stain;

(b) "actual" grade, which took account of the presence of borer holes and sap stain;

(c) "potential" grade, which took account of the possibility of eliminating defect caused by borers and stain along the outside edges. In wide boards of original high quality, it occasionally was advantageous to restore the piece to the "original" grade, even at the expense of footage, through edging off an inch or two in width to recover higher value. Edging a second time was not actually carried out, but the designation of "potential" grade and value ensured the highest possible return from the lumber. "Potential" grade had only a rather slight application in the white and red pine lumber, and none at all in the jack pine.

\section{Original Log Value Classes}

Since the occurrence of borer holes and stain causes the degrade of all lumber to a certain level regardless of original grade, percentage value loss is greater in originally high quality logs than in low quality logs. Log value based on volumes of "original grades" and prevailing wholesale lumber prices was employed as the simplest expression of original $\log$ quality and grade distribution.

After study of original $\log$ value distribution, white pine logs were divided into three classes of original value based on the value per $\mathrm{M}$ of the lumber recovered from the logs. In order to render the classes more easily recognizable, the percentage of certain grades in the lumber from the logs of each class was calculated. In the white pine lumber trade, No. 4 Common is regarded as the "break-even" grade; the experienced log grader looks for $40 \%$ No. 4 Common and better in a log lot to determine whether milling will be profitable. The percentage of these higher grades in the logs of each class was calculated. Where No. 4 Common and better exceeded $40 \%$, the percentage volume of No. 2 Common and better was also determined. The original log value classes for white pine may thus be described as follows:

\begin{tabular}{ccrll}
\hline Class & 1949 Value & \multicolumn{3}{c}{ Grades Contained } \\
\hline $\mathrm{A}$ & $\$ 40-\$ 70 / \mathrm{M}$ & $14 \%$ & No. 4 Common \& better \\
$\mathrm{B}$ & $\$ 71-\$ 100 / \mathrm{M}$ & $69 \%$ No. 4 Common \& better \\
& & $26 \%$ No. 2 Common \& better \\
$\mathrm{C}$ & $\$ 101 / \mathrm{M}$ plus & $100 \%$ No. 4 Common \& better \\
& & $72 \%$ & No. 2 Common \& better \\
\hline
\end{tabular}


The range in values in red pine is much more restricted than in white; therefore, only two log value classes were used:

\begin{tabular}{cll}
\hline Class & 1949 Value & \multicolumn{1}{c}{ Grades Contained } \\
\hline A & Less than $\$ 80 / \mathrm{M}$ & $\begin{array}{l}57 \% \text { Merchantable \& better, most } \\
\text { being Merchantable }\end{array}$ \\
B & More than $\$ 80 / \mathrm{M}$ & $\begin{array}{l}90 \% \text { Merchantable \& better, with } \\
\text { a good proportion of Clear and } \\
\text { Clearface lumber }\end{array}$ \\
\hline
\end{tabular}

\section{Assessment of Loss Through Degrade}

It is not feasible to show the effect of deteriorating agents by citing the original, actual, and potential grades and dimensions for each of the several thousand pieces of lumber from the sample trees. Market values, however, take account of dimension and grade, and serve as an adequate expression of the volume and quality output of logs or trees. The price schedules applied were wholesale rates in effect during the period when the work was carried out. Although these rates have been steadily increasing, comparison of the rates in effect in 1956 with those of 1949 showed that the percentage increase was apparently not greatly influenced by the grade of lumber. This is particularly true of the grades that embraced most of the lumber recovered in this study. Therefore, although recalculating the values for each piece of lumber on the basis of present prices might cause slight changes in value loss figures, the broad results of this study would undoubtedly remain the same as presented here.

The method of compiling the data for individual logs is illustrated in Table 1 by three logs representing different original qualities and degrade. Log 36-1 contained lumber of high original value, but borers and sap stain were very prevalent, degrade was heavy, and value loss was about 55\%. Log 29-1 contained lumber of low original value, and although borers and sap stain occurred generally, there was little opportunity for extensive degrade and loss was about $16 \%$. Log 48-1 contained lumber of high original value; there was extensive degrade; one piece (48-1-4) could be returned to original grade by edging one inch; and loss was about $46 \%$.

\section{RESULTS}

\section{White Pine}

Original Quality

The estimated gross contents (Doyle rule) of the 77 white pine logs from the sample trees was 7,527 f.b.m. The sawn output was 8,374.5 f.b.m., of which $14.2 \%$ was culled because of advanced heartwood decay, leaving a merchantable output of 7,188.5 f.b.m. 


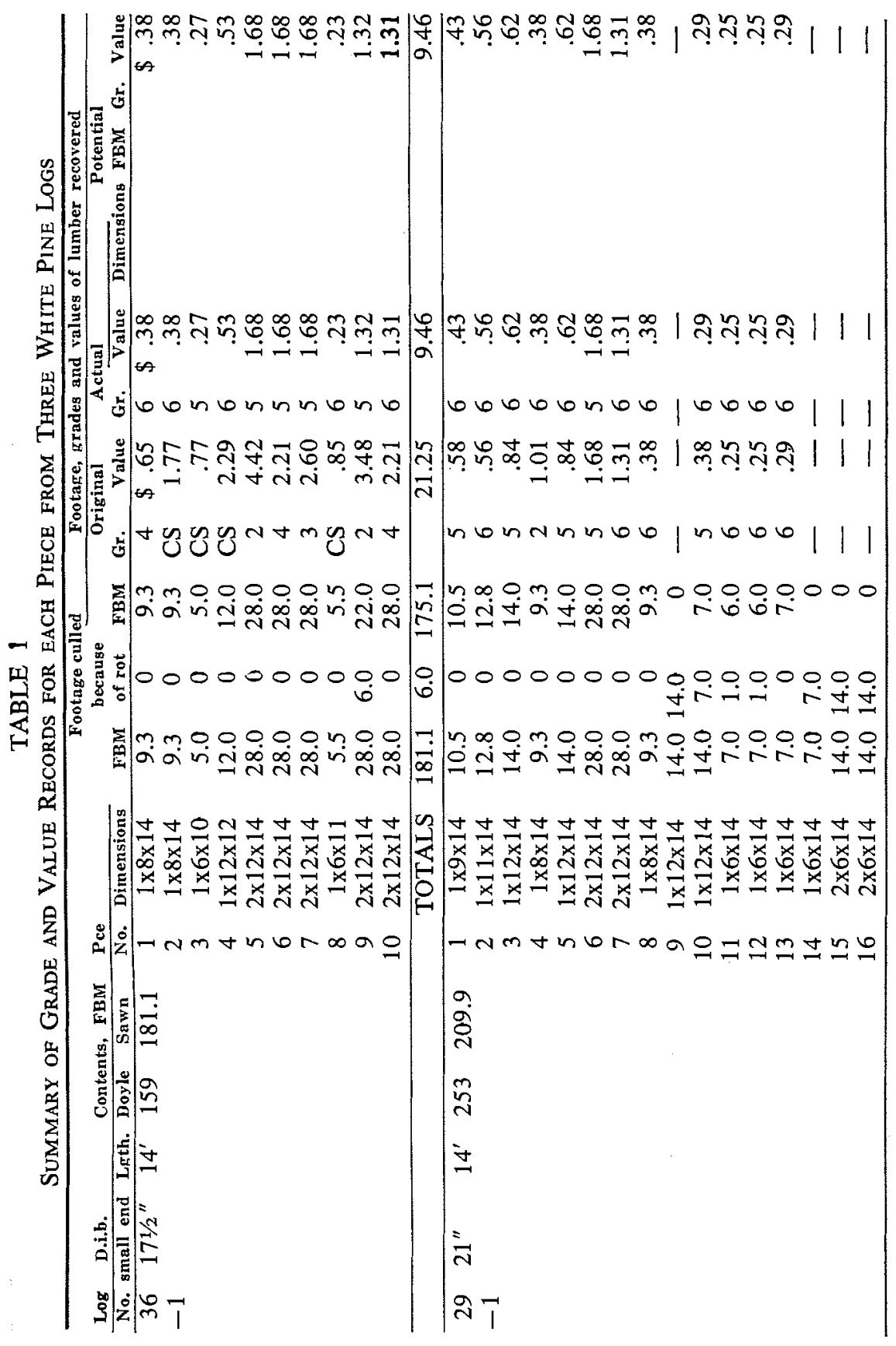



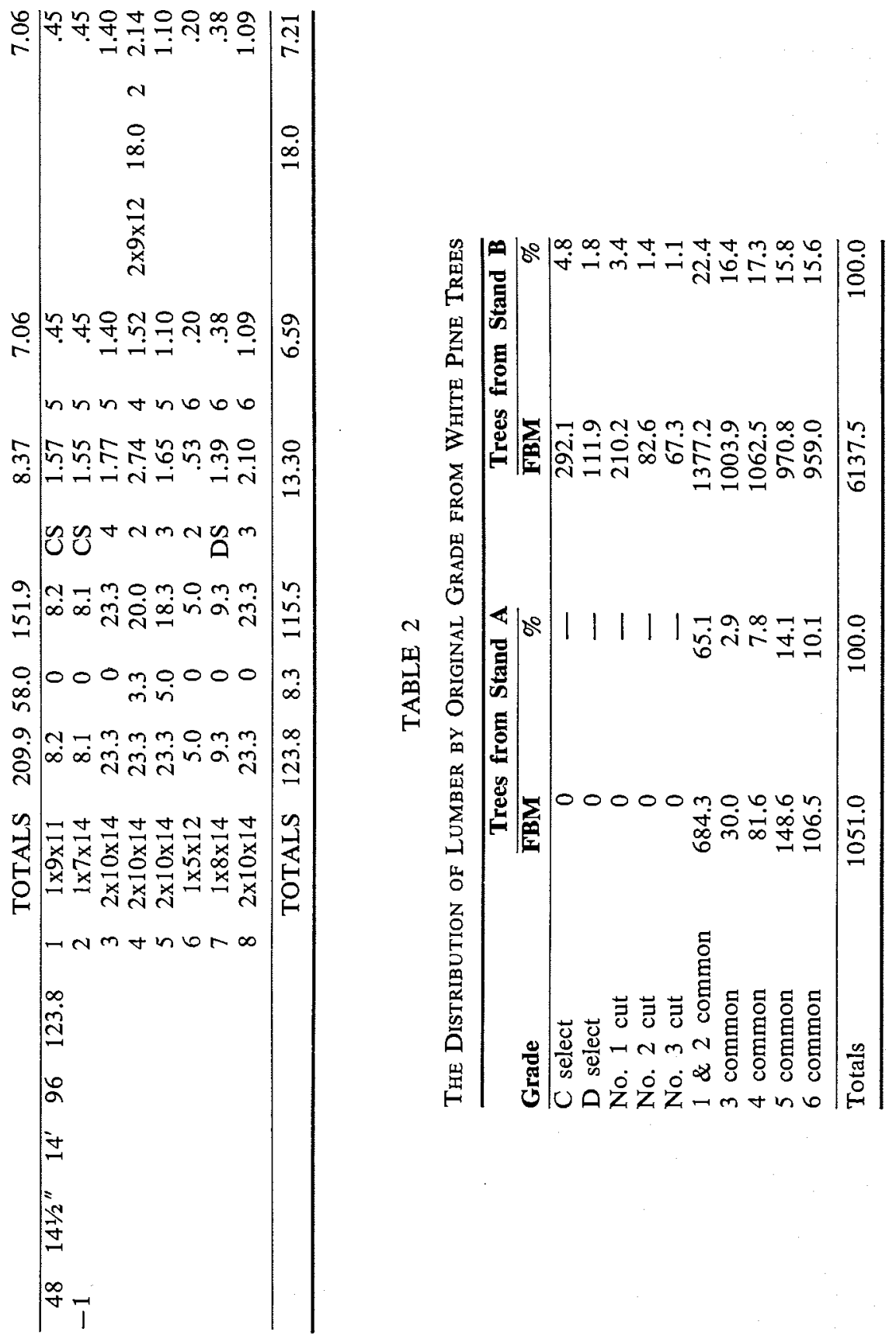
Advanced heartwood decay, which was quite independent of the fire, was more prevalent in the white pine than in the red pine. Many trees that were "sounded" while still standing were hollow to considerable heights. Such trees were not included in the sample. In several trees that were included, butt pieces 6 to 8 feet long were discarded owing to extensive butt rot. Of the 7,188.5 f.b.m. merchantable content of the 21 trees, $14.8 \%$ was of the lowest grade (No. 6 Common) because of incipient decay.

The wood rotting organisms responsible for cull and low grade in white pine were Fomes pini (Thore) Lloyd (Figs. 1 and 2), Corticium galactinum (Fries) Burt, Armillaria mellea (Vahl ex Fries) Quél., Merulius sp., and Poria subacida (Peck) Sacc., all of which caused decay of the heartwood.

A summary of the distribution of white pine lumber by original grade is shown in Table 2 . In the five trees from Stand A, $13 \%$ of the total sawn output was culled because of advanced decay, and $10.1 \%$ of the merchantable output was of the lowest grade. None of the lumber graded higher than No. 1 and No. 2 Common. The original value of the 1,051 f.b.m. was $\$ 103.48$, or $\$ 98.46$ per $M$.

In the 16 trees from Stand B, $14.3 \%$ of the total sawn output was culled because of rot, and $15.6 \%$ of the merchantable output was of the lowest grade. On the other hand, $12.5 \%$ of the merchantable output fell in the higher grades, No. 3 Cut and better. The original value of the $6,137.5$ f.b.m. was $\$ 581.00$, or $\$ 94.66$ per M. The advantage of the larger size of trees in Stand B, in producing some of the better grades, was offset by the greater prevalence of advanced decay which led to cull, and of incipient decay which reduced the grade of much of the merchantable output.

\section{Quality of Lumber as Influenced by Borers and Stain}

Borers and sap stain were very prevalent in the white pine trees dying or dead from the effects of the fire. In trees that were killed early in the summer of 1948 , the average number of borers entering the wood was 2.4 per square foot of $\log$ surface (inside bark) in November, 1949. About $75 \%$ of the entrance holes were made by deep-boring Monochamus species, and the maximum depth of penetration into the wood was 8.5 inches; generally the depth of penetration ranged from 4 to 7 inches in different logs. The sapwood was extensively stained by Ceratostomella sp. to a maximum depth of 3 inches, and characteristically from $1 \frac{1 / 2}{2}$ to 2 inches in different logs.

In white pine trees that were dying gradually in 1949 from the effects of the fire, borer holes in November averaged 2.6 per square foot of log surface (inside bark), but only about $20 \%$ of these were caused by Monochamus species. Attack was very light in the butt logs of these trees, but fairly heavy in the second, third, and fourth logs. Penetration into the wood did not exceed 4 inches in November, 1949, and usually was less than 2 inches. Sap stain to a depth of 4 inches was recorded in one log from this group, but usually was less than 2 inches. In some logs stains had not yet become established. No sapwood decays were encountered in the white pine trees killed in 1948, or dying in 1949. 
JUNE, 1958

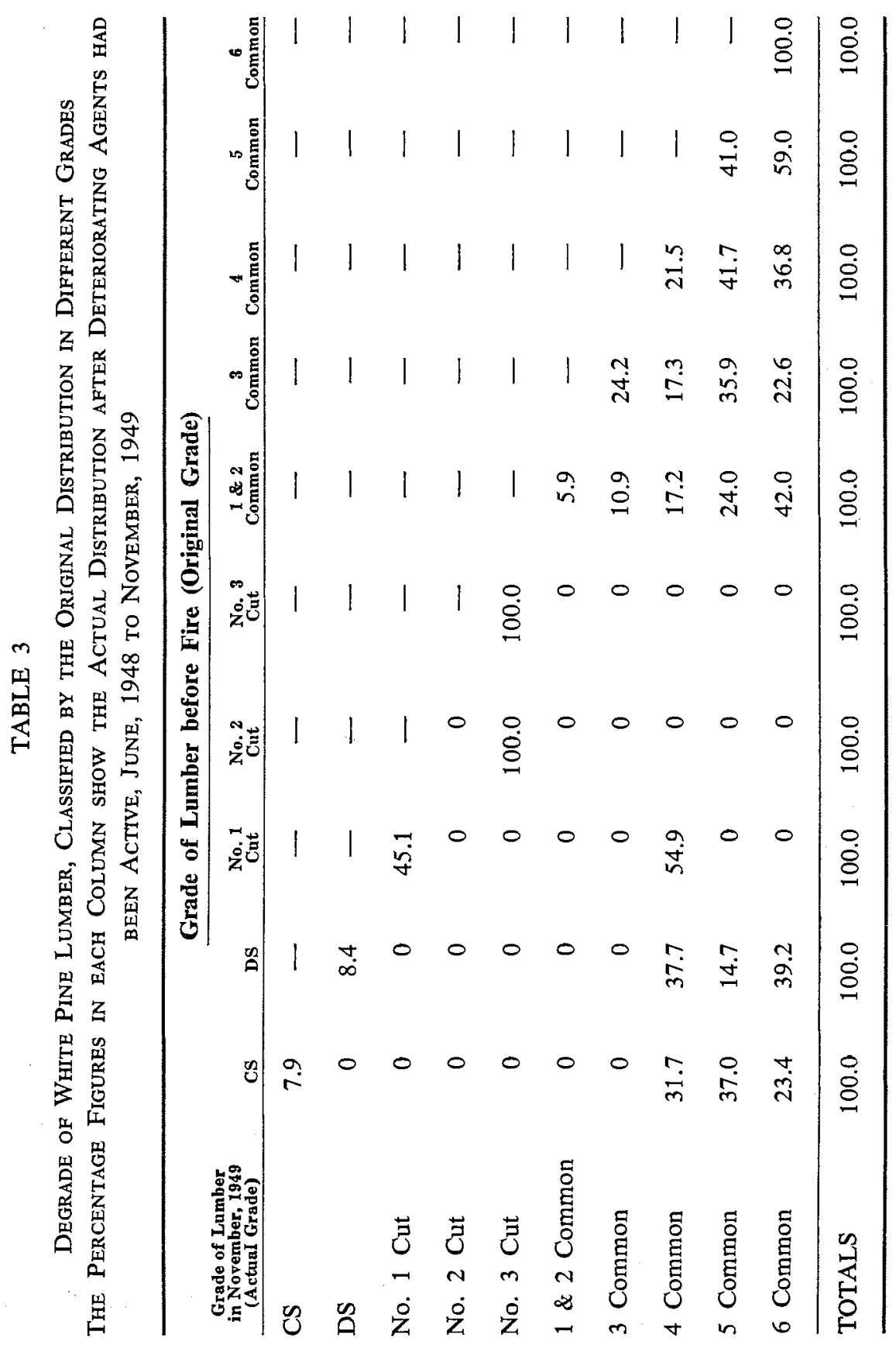


Deterioration of white pine lumber in fire-killed trees is illustrated in Figs. $3,4,6,7$, and 8. Fig. 5 shows freedom from deterioration in a white pine tree, which though dying from the effects of crown fire, remained free of borers until 1949.

The extent of degrade within each of the original grades, as a consequence of deterioration following fire, is shown in summary form for all the white pine lumber from dead or dying trees in Table 3 . The extent of degrade among the higher grades is indicative, but not necessarily reliable owing to the small volumes included in the sample. The common grades were more adequately represented, and the data are more reliable. Only $5.9 \%$ of the lumber which before the fire would have been graded as No. 1 \& 2 Common escaped degrade, and $66.0 \%$ of it fell to No. 5 \& 6 Common as a consequence of borer holes and sap stain.

The influence of severity of burn injury on the extent of degrade in firedamaged white pine is shown in Table 4, which gives the actual grade distribution 17 months after the fire in material that would have been graded originally as $1 \& 2$ Common. The data are segregated on the basis of original log value, as previously explained, and show that in each log value class, degrade was much more severe in lumber from severely burned trees; none of this material retained its original grade and most of it was degraded to $5 \& 6$ Common. In the less severely burned trees, a considerable proportion of the lumber remained in the better Common grades.

\section{Value Loss in White Pine}

The average percentage value loss in fire-damaged white pine is given in Table 5 for the three original log value classes within each of the two burninjury groups. Percentage loss was greater in lumber from trees that had suffered severe burn injury, particularly in the highest quality logs. The heaviest loss, about $59 \%$ on the average, occurred in the best logs from the trees that had suffered severe fire injury.

TABLE 4

Degrade in White Pine Lumber

Actual Percentage Distribution of Originally No. $1 \& 2$ Common LUMBER 17 MONTHS AFTER FIRE

\begin{tabular}{|c|c|c|c|c|c|}
\hline \multirow[b]{2}{*}{$\begin{array}{c}\text { Grade of } \\
\text { Lumber } \\
\text { Nov, 1949 }\end{array}$} & \multicolumn{3}{|c|}{ Trees Lightly to Moderately Burned } & \multicolumn{2}{|c|}{ Trees Severely Burned I } \\
\hline & $\begin{array}{c}\text { Orig. Val. } \\
\text { A. } \\
\text { (low) }\end{array}$ & $\begin{array}{c}\text { Orig. Val. } \\
\text { (med.) }\end{array}$ & $\begin{array}{c}\text { Orig. Val. } \\
\text { (high) }\end{array}$ & $\begin{array}{c}\text { Brig. Val. } \\
\text { (med.) }\end{array}$ & $\begin{array}{c}\text { Orig. Val. } \\
\text { C. } \\
\text { (high) }\end{array}$ \\
\hline $1 \& 2$ Com. & 13.3 & - & 16.2 & - & - \\
\hline 3 & - & 31.8 & 29.2 & - & - \\
\hline 4 & 26.1 & 40.5 & 30.3 & 一 & 8.3 \\
\hline 5 & - & - & 22.7 & 52.6 & 24.9 \\
\hline 6 & 60.6 & 27.7 & 1.6 & 47.4 & 66.8 \\
\hline Total Vol. (fbm) & 35.2 & 113.3 & 589.1 & 128.0 & 946.5 \\
\hline
\end{tabular}


There was a tendency for percentage loss to decrease with increasing log size, within the logs making up any one series defined by original log value and severity of burn injury. Such a relationship is entirely consistent with the factors that influence original grade and value, and with those that influence degrade. However, no series of logs was extensive enough to warrant a formal expression of percentage loss with log size.

An attempt was made to correlate the value loss in the various logs with the density of borer entrance holes in the sample blocks taken from the log ends before milling. This was unsuccessful, however, since entrance holes had not been adequately classified according to the wood borers that had made them. Unless this can be done, a count of the entrance holes in the wood surface may give an erroneous estimate of the internal insect damage, since some species bore deeply and extensively, whereas others make only a simple, shallow penetration.

Attention was then turned to the possible relationship of value loss in logs to the density of borer holes appearing on the surfaces exposed by splitting the sample blocks radially into 12 nearly equal sections. However, careful inspection of the data failed to reveal any dependence of value loss on number of borer holes, principally because stain is an equal cause of degrade with holes. Examples of this are cited in Table 6. The first pair of logs was from trees lightly to moderately burned, and in original value class $\mathrm{B}$; the second pair was from a severely burned tree, and in original value class $C$. The examples show that heavy stain, accompanying a small or moderate number of borer holes, caused value loss similar to that brought about by heavier incidence of borer holes in company with light to moderate stain.

In view of the fact that deterioration of fire-killed white spruce was found to be correlated with the extent of bark charring (Richmond and Lejeune, 1945), is was thought worth while to investigate this feature in the present study. The pine logs were segregated into series on the basis of original log value and height in tree, and these were divided into three sub-series: (1) logs with no charring or only slight charring; (2) logs with moderate charring; and, (3) logs with heavy charring. Variations in percentage loss between sub-

TABLE 5

Average Per Cent Value loss in White Pine

\begin{tabular}{ccc}
\hline $\begin{array}{l}\text { Original Log } \\
\text { Value Class }\end{array}$ & $\begin{array}{c}\text { Logs From Trees Lightly } \\
\text { to Moderately Burned }\end{array}$ & $\begin{array}{c}\text { Logs From Trees } \\
\text { Severely Burned }\end{array}$ \\
\hline A & 13.6 & 17.2 \\
$(\$ 40-\$ 70 / M)$ & 31.0 & 37.4 \\
B & 33.2 & 58.8 \\
$\left(\begin{array}{c}\$ 11-\$ 100 / M) \\
\text { C }\end{array}\right.$ & & \\
\hline
\end{tabular}


series were small and showed no consistency, and it is concluded that degree of bark charring in the fire-killed pine in the Mississagi area was not related to deterioration. White pine bark is considerably thicker than white spruce bark, and even in the case of the heaviest charring, only the outside surface had been burned. Wood-boring larvae had developed normally between the bark and the wood.

\section{Red Pine}

Original Quality

The estimated gross contents (Doyle rule) of the 85 logs from the 22 red pine trees was 6,745 f.b.m. The sawn output was $8,218.9$ f.b.m. of which only $0.47 \%$ was culled, leaving a merchantable output of $8,179.9$ f.b.m.

All cull occurred in the older trees of Stand B and Stand C. Incipient rot was unimportant, as only $0.51 \%$ of the total merchantable lumber was of the lowest grade (No. 3 cull). Reduction to the lowest grade because of incipient rot affected $0.23 \%$ of the merchantable lumber in sample trees in Stand A, $0.55 \%$ in Stand B, and $1.24 \%$ in Stand C. Fomes pini and Polyporus schweinitzii Fries were the organisms causing heartwood decay in red pine.

The distribution of lumber by original grade is summarized in the left half of Table 7. There was comparatively little difference in the distribution of grades in sample trees from Stand A, and from Stands B and C. The overall average original value of the $8,179.9$ f.b.m. that made up the sample was $\$ 84.64$ per $\mathrm{M}$.

\section{Quality of Lumber as Influenced by Stain and Borers}

Wood-borer entrance holes occurred at the rate of 1.4 per square foot of $\log$ surface in red pine trees that were killed by fire in May, 1948. However, only about $20 \%$ of these were caused by the deep-boring species. The maximum depth of penetration was 7.5 inches, but penetration to depths of 1 to 3 inches was more typical. Sap stain penetrated to a maximum depth of 6 inches, 2 to 4 inches being typical. The fungi Polyporus abietinus Dicks. ex Fries and Merulius sp. had caused a slight amount of sapwood decay by November, 1949. Most of the degrade in the fire-killed red pine was because of sap stain.

In red pine trees that died during 1949 from the effects of the fire, borer entrance holes averaged 2.5 per square foot of log surface in November, 1949.

\section{TABLE 6}

Similarity of EFFect of Holes and Stain on Value of FrRe-Damaged White Pine Logs

\begin{tabular}{|c|c|c|c|}
\hline$\overline{\log N o .}$ & No. of Borer Holes ${ }^{1}$ & Stain & $\%$ Value Loss \\
\hline $35-3$ & 13.5 & light & 32.6 \\
\hline $41-1$ & 1.0 & heavy & 30.6 \\
\hline $2-4$ & 41.0 & moderate & 60.6 \\
\hline $2-1$ & 11.0 & heavy & 64.8 \\
\hline
\end{tabular}


However, less than $1 \%$ of these were caused by deep-boring species and penetration did not exceed 1.5 inches. Many grubs were still on the wood surface. Sap stain penetration ranged up to 3 inches in this group of trees. Deterioration typical of red pine lumber from firekilled trees is shown in Fig. 9.

A summary of the distribution of red pine lumber by actual grade is shown in the right half of Table 7. Degrade was somewhat greater in the trees from Stand A. The average actual value of lumber from Stand A was $\$ 69.84$ per $M$, representing a value loss of $15 \%$. The average actual value of lumber from Stands $B$ and $C$ was $\$ 80.45$ per $M$, representing a value loss of $7 \%$. However, seven trees from these stands were not killed outright by the fire in 1948, dying gradually during 1949 . They had not been appreciably affected by deteriorating agents by November of that year. Loss in these seven trees was only $4.4 \%$.

A similar, though less marked, relationship between severity of burn and degrade occurred in red pine as in white pine. Table 8 shows that in both original log value classes a greater percentage of originally Merchantable lumber was degraded in severely burned trees. The comparatively lighter damage in red pine, compared with that in white pine (Table 4), is demonstrated by the fact that none of the groups represented in Table 8 was completely degraded, i.e., some material in each retained its original grade. The percentage volume of lumber retaining its original grade was smaller in severely burned trees.

\section{Value Loss in Red Pine}

Percentage value loss in red pine was influenced by the severity of burn suffered by the tree, and by original $\log$ value. Loss ranged from $7.8 \%$ in low quality logs from lightly to moderately burned trees, to $17.3 \%$ in high quality

TABLE 7

Distribution of Red Pine lumber Before the Fire (Original Distribution) aNd after Agents of Deterioration had BeEn ACTIVE, JUNE 1948 TO NOVEMBER 1949 (ACTUAL DISTRIBUTION)

\begin{tabular}{|c|c|c|c|c|c|c|c|c|}
\hline \multirow{3}{*}{ Grade } & \multicolumn{4}{|c|}{ Original Distribution } & \multicolumn{4}{|c|}{ Actual Distribution } \\
\hline & \multicolumn{2}{|c|}{$\begin{array}{c}\text { Trees from } \\
\text { Stand A }\end{array}$} & \multicolumn{2}{|c|}{$\begin{array}{c}\text { Trees from } \\
\text { Stand B \& C }\end{array}$} & \multicolumn{2}{|c|}{$\begin{array}{l}\text { Trees from } \\
\text { Stand A }\end{array}$} & \multicolumn{2}{|c|}{$\begin{array}{c}\text { Trees from } \\
\text { Stand B \& C }\end{array}$} \\
\hline & $\overline{\text { FBM }}$ & $\%$ & FBM & $\%$ & FBM & $\%$ & FBM & $\%$ \\
\hline $\begin{array}{r}\mathrm{Clea} \\
\mathrm{cl}\end{array}$ & 17.9 & 5.4 & 47 & 1. & 18.2 & & 328 & 8. \\
\hline Merchantable & 90.6 & 72.7 & 2419.1 & 58.9 & 711.9 & .5 & 1566.4 & 38.2 \\
\hline No. $1 \mathrm{c}$ & 859.9 & 21.1 & 1094.4 & 26.6 & 2476.2 & 60.9 & 1663.2 & 40.4 \\
\hline No. 2 cull & 22.7 & 0.6 & 88.9 & 2.2 & 829.6 & 20.4 & 511.6 & 12.4 \\
\hline No. 3 & 9.3 & 0.2 & 33.0 & 0.8 & 34.5 & 0.8 & 40.0 & 1.0 \\
\hline Totals & 4070.4 & 100.0 & 4109.5 & 100.0 & 4070.4 & 100.0 & 4109.5 & 100.0 \\
\hline
\end{tabular}


logs from severely burned trees (Table 9). The differences marking the various groups defined by burn severity and original value are much less than in white pine. This appears to stem from two causes: (1) less variation in original quality in red pine; and, (2) much lighter damage by both fire and insects in this tree species. Moreover, wood-staining fungi ordinarily gain entry into the tree through insect galleries, and reduction in number of the latter would tend to reduce the importance of stain.

There was no evidence of any dependency of deterioration upon degree of bark charring in red pine. Wood-borers attacked heavily-charred sections of trees, where bark scales were partly consumed. Only in a few cases was the bark burned off to expose the wood. This was confined to the lower part of the trunk where windfalls rested against the tree and sustained the fire.

\section{SUMMARY AND Discussion}

Salvage of huge quantities of timber killed by fire over large, relatively inaccessible areas is difficult in the comparatively short time before insects, stain, decay-causing organisms, and ultimately, wind damage, render the wood economically valueless. This is particularly true in operations for sawlogs, in stands of moderate-size trees that deteriorate rapidly, and in areas where improvements have to be made for the extraction of the salvaged timber.

The present study shows that white and red pine trees that suffered only light to moderate burn injury and consequently escaped immediate mortality in the Mississagi fire of May, 1948, sustained relatively slight damage from deteriorating agents by November, 1949 . The average value loss in white pine trees of this type ranged from $13.6 \%$ in low quality logs to $33.2 \%$ in high quality logs. In red pine, the loss averaged about $8 \%$. Most of these trees, and particularly the red pine, were still salvable 17 months after the fire.

Conditions were quite different in trees that were severely burned and killed outright. These trees, whether white or red pine, were much more heavily attacked by deep-boring species of beetles than were the slowly dying trees. In white pine, average value loss ranged from $17.2 \%$ in low quality logs to $58.8 \%$ in high quality logs. The degrade of almost all $1 \& 2$ Common lumber from these trees to $5 \& 6$ Common indicates clearly the unattractive salvage

TABLE 8

Degrade in Red Pine Lumber

Actual Percentage Distribution of Originally Merchantable Lumber 17 Months After FIre

\begin{tabular}{|c|c|c|c|c|}
\hline Grade of Lumber & Trees Lightly to & Moderately Burmed & Trees Sey & y Burned \\
\hline Nov. 1949 & Orig. Val. A & Orig. Val. B & 0rig. Val. A & Orig. Val. B \\
\hline Merchantable & 36.4 & 63.3 & 15.3 & 41.1 \\
\hline No. 1 Cull & 55.4 & 33.9 & 63.4 & 52.3 \\
\hline No. 2 Cull & 7.3 & 2.8 & 21.3 & 6.6 \\
\hline No. 3 Cull & 0.9 & - & - & - \\
\hline Total Volume (f.b.m.) & 1055.0 & 1909.6 & 1107.0 & 1126.3 \\
\hline
\end{tabular}


TABLE 9

Average Percent Value Loss in Red Pine

\begin{tabular}{ccc}
\hline $\begin{array}{c}\text { Original Log } \\
\text { Value Class }\end{array}$ & $\begin{array}{c}\text { Logs From Trees Lightly } \\
\text { to Moderately Burned }\end{array}$ & $\begin{array}{c}\text { Logs From Trees } \\
\text { Severely Burned }\end{array}$ \\
\hline $\begin{array}{c}\text { A } \\
\text { under } \$ 80 / M\end{array}$ & 7.8 & 13.0 \\
B & 8.6 & 17.3 \\
over $\$ 80 / \mathrm{M}$ & & \\
\hline
\end{tabular}

prospects in severely burned white pine. There was less variation in original quality of red pine trees, and lighter attack by harmful species of wood-borers than in comparably burned white pine, so that average value loss ranged from $13.0 \%$ to $17.3 \%$. The recovery value in November, 1949, of red pine logs was in practically all cases higher than that of white pine logs. Whether economic salvage of white and red pine killed outright in a similar fire could continue longer than a year after the fire would depend on factors, such as a greatly narrowed margin between relatively fixed production costs and a reduced sale value of the product, that are outside the scope of the investigations reported here. Moreover, it should be emphasized that this study was concerned only with deterioration following an early summer fire. Damage by borers and stain might have been quite different had the fire occurred, for example, during the autumn.

It is worth noting that one tree, a white pine of 30.5 inches d.b.h., failed to exhibit the same effects of fire and insect attack observed in all the other trees sampled. First, it was the only tree encountered that had suffered only from crown fire. Secondly, though it had apparently been killed in 1948, this tree was in excellent condition in November, 1949, and none of the lumber from it, which included the largest proportion of Select boards obtained from any tree taken, was degraded (Fig. 5). It is difficult to account for the tree's apparent immunity from insect attack except on the basis of the observation that the wood was extremely sappy. It seems possible, although no other evidence was found to corroborate it, that the abrupt cessation of transpiration by consumption of the foliage by crown fire might contribute to an abnormally high moisture content in the tree which in turn might delay severe attack by insects and fungi.

A feature of general interest was the continued development of the wood borers, and their ultimate emergence as adults, when infested lumber was transferred to heated storage in December (Fig. 10). Continued development, under suitable temperature conditions, may be expected when infested lumber is put in service soon after sawing. However, once the adults have emerged, the infestation will cease.

\section{ACKNOWLEDGMENTS}

The authors gratefully acknowledge assistance received from numerous co-operators in carrying out this study. J. F. Sharpe, J. A. Brodie, J. H. Hope and Q. F. Hess of the Ontario Department of Lands and Forests arranged for 
financing the mill operations and lumber transportation. D. D. Mix, then Chief Forester of the J. J. McFadden Lumber Company, provided camp accommodation. R. F. Tetreault and W. Desbiens provided assistance in the milling operations. W. J. LeClair of the Canadian Lumbermen's Association arranged for grading of the lumber by T. M. Callaghan. J. E. Bier identified the fungi causing rot in the pine lumber, and R. F. Fytche assisted with compilations and preliminary analysis of the data. D. C. Anderson provided the photographs used in this paper. The assistance of numerous members of the Forest Insect Laboratory, Sault Ste. Marie, Ontario, was indispensable in carrying out the logging, milling, and hauling operations.

\section{REFERENCES}

BASHAM, J. T. 1958. Studies in forest pathology. XVII The pathological deterioration of firekilled pine in the Mississagi region of Ontario. Can. Dept. Agr. Pub. 1022.

GARDINER, L. M. 1957. Deterioration of fire-killed pine in Ontario and the causal wood-boring beetles. Canad. Ent. 89: 241-263.

KIMMEY, J. W. and R. L. FURNISS. 1943. Deterioration of fire-killed Douglas-fir. U.S.D.A. Tech. Bull. No. 851. 61 pages.

RICHMOND, H. A. and R. R. LEJEUNE. 1945. The deterioration of fire-killed white spruce by wood-boring insects in northern Saskatchewan. Forestry Chronicle 21 (3): 168-192.

SROLKO, A. J. 1947. Deterioration of fire-killed pulpwood stands in eastern Canada. Forestry Chronicle 23 (2): 128-145. 